\title{
THE EFFECT OF CREATIVE PROBLEM SOLVING WITH THE INTERVENTION SOCIAL SKILLS ON THE PERFORMANCE OF CREATIVE TASKS
}

\author{
Hadi SURYANTO (D) 1,2*, I Nyoman Sudana DEGENG (D) ${ }^{3}$, \\ Ery Tri DJATMIKA (D) ${ }^{4}$, Dedi KUSWANDI (D) ${ }^{3}$ \\ ${ }^{1}$ Department of Learning Technology, Faculty of Education, State University of Malang, \\ Jl. Semarang No. 5, Sumbersari, Kec. Lowokwaru, Malang City, East Java 65145, Indonesia \\ ${ }^{2}$ Department of PPKn, Faculty of Social Sciences and Humanities, PGRI Adi Buana University of \\ Surabaya, Jl. Dukuh Menanggal XII, Kec. Gayungan, Surabaya City, East Java 60234, Indonesia \\ ${ }^{3}$ Department of Education Technology, Faculty of Education, State University of Malang, \\ Jl. Semarang No. 5, Sumbersari, Kec. Lowokwaru, Malang City, East Java 65145, Indonesia \\ ${ }^{4}$ Department of Management, Faculty of Economics, State University of Malang, Jl. Semarang No. 5, \\ Sumbersari, Kec. Lowokwaru, Malang City, East Java 65145, Indonesia
}

Received 31 March 2020; accepted 13 May 2021

\begin{abstract}
This research aims to determine the social skills intervention with the student's ability to solve problems creatively towards understanding the concepts and procedures: the objectives of learning. A quasi-experimental research design was used to see the interaction between attitudes and treatments. The research sample was students who took computer courses in reality-based laboratories in vocational schools. Data analysis was performed using descriptive analysis techniques and inferential statistical multivariate analysis of variance two paths. Creative problem solving is intervened by a background in social skills to understand concepts and procedures. Social skills have a greater influence on the creative process. This can be seen when giving creative problem-solving tasks. The abilities they have, about; readiness to learn, the ability to understand one's own needs, and the ability to understand one's own learning style, greatly support the performance of their creative assignments. At the same time, external factors have less influence on the performance of creative tasks. These external factors are influenced by the class social environment, group formation, and class management. Students who have high social skills find it easier to complete creative tasks, and students who have low social skills have problems adapting and adjusting to the learning process.
\end{abstract}

Keywords: comprehension orientation, cooperative learning, creative performance, learning strategies, social skills.

\section{Introduction}

The implementation of learning in the classroom by providing direct experience with the application of problem-solving strategies is the main goal of learning at this time. A series of structured and systemic activities will form a creative process to solve the problems

*Corresponding author. E-mails: hadi.suryanto.1601219@students.um.ac.id; hsuryanto3@gmail.com 
they face through direct practice in everyday life. Needing serious attention is a factor that influences the creative process in learning carried out in the laboratory. Creative process activities require repeated practice so that they are available to solve problems creatively. Therefore, training students to determine problems, convey ideas and generate creative solutions needs to be the main goal of learning activities. The creative process is carried out by giving assignments to be completed creatively. These skills are needed today where a very open-source of information and many options to access requires the ability to find enough information, as well as the ability to choose the information needed. The implementation of problem solving-based learning creatively also gives them experience in working as a team through collaborative learning. This kind of experience can train them to work together in completing a given project. In collaboration activities between group members and between problem-solving groups creatively through the delivery of ideas and solutions found will be more diverse and have many alternative solutions obtained. This learning activity requires interaction between students and students with teachers. Organizational features have a positive relationship with the assessment of creativity within the members of the organization, and these relationships are mediated by a positive mood (Lin \& Chang, 2020). Learning in Indonesia is still dominated by teacher-centered learning methods through the teacher explaining in front and students listening so that learning is only oriented towards cognitive learning outcomes. Indonesian students are still not maximal in the skills of the psychomotor and affective aspects. The result is that the student's ability in the creative aspect is low. So that Indonesia is ranked 2nd from the bottom 81 out of 82 countries (Florida et al., 2011). This also occurs in vocational schools where these schools are supposed to create skilled workers who are ready to work, but what happens to many vocational school students are not able to adapt to the work environment. A lesson is carried out at school as long as it is not able to develop students' creative abilities (Khuziakhmetov \& Gorev, 2017). Providing job completion skills through first-class experience is essential for vocational school students. Related to the direct experience of solving creative problems, the ability to adapt, adjust to the creative process, and supportive behaviors outside of the learning activities have a huge influence. Therefore, it is necessary to obtain sufficient information on whether the background of students' social skills has an influence on the creative process that occurs in the given creative assignment. Although perceived architectonic details of the physical work environment do not have a direct effect on occupants' creativity, there is also a mediating effect through positive moods (Lin \& Chang, 2020). Social skills make it easier for them to adapt to the creative process that takes place in creative problem-solving. There are three parameters of skills in learning practice, namely: 1) social skills to adapt in learning activities, for example, asking questions, answering teacher questions, listening to teacher explanations and discipline following learning; 2) skills that support the learning process, for example, the ability to interact with friends, helping behaviour, asking group assignments and the ability to work together; 3) skills outside of learning activities for example; readiness to learn, ability to understand one's own needs, ability to understand one's own learning style, take responsibility.

The existence of differences in students' social skills as a characteristic of student backgrounds needs the attention of all parties as consideration for program implementation. Whether these differences in student characteristics will affect interactions in class, as well 
as affect the creative process that occurs and the end result is that students have the skills to solve problems creatively on a given problem. Therefore, it is necessary to do thorough research on the use of learning strategies that are associated with social skills on the performance of creative tasks that take place during creative problem-solving. The identification of students' social skills needs to be taken seriously in determining further courses in the classroom. Differences in social skills that characterize individuals must be detected early so that teachers and students know and become a consideration for teachers and schools to provide self-assessments in projects carried out in the classroom. This activity is important as a strategy to improve the quality of learning in the classroom by considering the characteristics of students.

\section{Literature review}

Creative problem solving is a problem-based learning strategy that begins by exploring various problems found, formulating problems, providing ideas in the form of solutions offered, and formulating solutions used creatively. Creativity reveals the issues given, discussed, and the discovery of ideas. Creative problem solving can also be determined by external factors as a person's skill in achieving the goals needed through the creative process in order to find new solutions creatively. The importance of communication in the educational process means that teachers must also have various competencies such as personality, communication, social, lifelong learning, methodology, planning, organization, leadership, and assessment, respondents in distinguishing some of the most significant problems for them (Navickiene et al., 2019). Research states that creative problem solving can provide skills to students to solve problems that are solved every day (Abdulla \& Cramond, 2018; Basadur et al., 2014; Carver \& Scheier, 2005; Chowdhry, 2016; Wang et al., 2008). This skill requires a long practice consisting of creative processes, and this activity is very important in the development of social skills in the field of creativity. The activity evaluates ideas and involves many people making decisions by thinking creatively in life every day - the process of creating new ideas and still discussing how to think differently.

Progression of the current problems. Student characteristics are important for individual learning needs. Metacognition is an important learner characteristic because it involves the process of thinking about thinking (Carver \& Scheier, 2005; Flavell, 1979; Isari et al., 2016; Schult et al., 2017). Some experts claim that creative ways of solving problems can be solved through complexity and growing. Without better metacognition, students will have difficulty learning complex topics in their learning environment. Difficulty in planning, setting goals, choosing effective strategies (Ames \& Archer, 1988; Azevedo et al., 2004). Gaps in the application of creative problem solving without looking at interventions by internal and external social skills. Social skills are an important factor in shaping the creative process of solving problems creatively (Gillies, 2019). Social skills in the learning process are; ability to adapt to learning activities, skills that support the learning process, and skills possessed outside the learning process (Merrell, 2001). Therefore realistic solutions for the application of creative solving need to take into account the characteristics of students by knowing the internal and external factors of their social skills background. Problem-solving activities are creatively 
influenced by the intrinsic motivation that tends to have a strong influence on unfavorable working conditions caused by work-life balance (An, 2019). Skills are an important factor in the creative process of creative problem-solving. Engaging the social skills of students with low metacognitive abilities is not capable of facilitating their own abilities. How students learn to solve problems, find problems and convey ideas requires their social skills. The impact is less creative in understanding the concepts and procedures intended. In addition, the level of students understanding of problems given creative problem-solving strategies during the problem-solving process is very important (Paas et al., 2001; Paas \& van Merriënboer, 1994; Schmidt et al., 2007; Schult et al., 2017; Sternberg, 1985).

This research is expected to provide students with creative task performance skills in finding problems, gathering information, conveying ideas and finding creative solutions to problems given through direct experience based on performance in the laboratory.

\section{Research objectives and hypotheses}

This study has several research objectives, including; 1) get background information on students' social skills (skills to adapt to learning activities, skills that support the learning process and skills outside the learning process); 2) knowing the influence of social skills related to the creative performance process (finding information, formulating problems, conveying ideas and finding solutions) in field practice-based learning in the laboratory; 3 ) determine the effect of implementing learning strategies and social skills on students' ability to understand computer creation courses' concepts and procedures. Research hypotheses include:

1) there are differences in the use of learning strategies and social skills on the performance of creative tasks;

2) there are differences in learning strategies and social skills on learning outcomes in understanding concepts and procedures;

3) there is an interaction of learning strategies and social skills on learning outcomes in understanding concepts and procedures.

\section{Method}

\subsection{Research design}

This experimental research design uses a quasi-experimental research design. The choice of this research design was chosen because the background ability of students as research subjects could not possibly be the same, so a quasi-experimental research design was chosen. Questionnaires were given at the beginning of the learning program to find out three parameters of their social skills, namely skills to adapt to learning activities, skills that support the learning process, and skills outside the learning process. This is as initial information about the characteristics of each student. These social skills are divided into two categories, namely low social skills and high social skills. Then make observations about the creative process in the classroom which consists of 4 parameters, namely extracting information, formulating problems, conveying ideas, formulating solutions. And learning outcomes are carried out by 


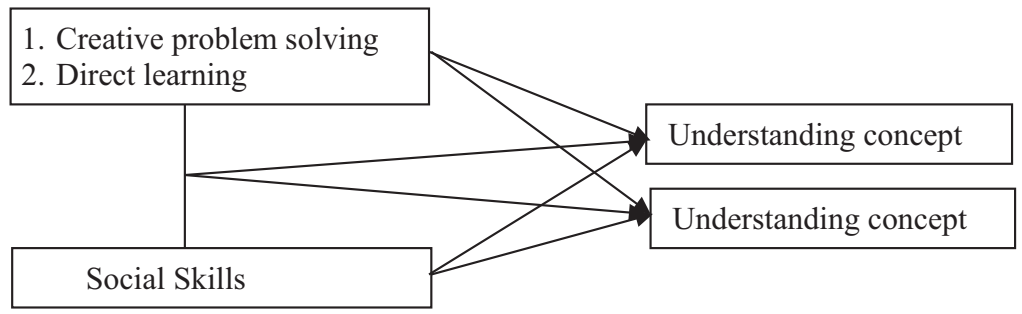

Figure 1. Research design (source: created by authors)

pre-test and post-test. Learning outcomes are in the form of student knowledge on understanding concepts and procedures for assembling computers. With creative problem solving, learning strategies, and direct learning as independent variables, social skills as moderator variables and learning outcomes, understand concepts and procedures as dependent variables in computer and network engineering majors in computer assembly courses (Figure 1). Subject selection is made by cluster sampling.

\subsection{Participants}

Class 9 students' research subjects consisted of two classes, and the number of students was 72 (36 and 36) in vocation education, Indonesia. The sample is divided into 36 respondents "control class and 36 respondents" experimental class with an error margin of $1 \%$. The research subjects were students who were taking a computer-assembling course. Sample selection was made by cluster sampling.

\subsection{Data analysis}

The data of the research results were tested statistically using descriptive analysis techniques and statistical analysis of multivariate inferential variants of two paths. Researchers used multivariate analysis of variance to find out the relationship between social skills in students and the creative process in the classroom in solving creatively given problems. The final result of the analysis of the data obtained is used to know the creative process during learning through working practices in the laboratory with the social skills possessed and its influence on the results of learning understanding concepts and procedures.

\subsection{Data collection}

The research data was obtained by giving a social skills questionnaire before the program began to find out the background of students' social skills with three parameters of their social skills, namely the skills to adapt to learning activities, skills that support the learning process, and skills outside the learning process. After the information on social skills was obtained together with the results of other research, the information on the results of social skills was grouped into two categories where the first group were students who had low social skills and the group of students who had high social skills. This activity is carried out to facilitate the analysis of research data. The scope of social skills studied includes the students' ability 
to follow the learning process, students' ability to support the learning process, and students' abilities outside of learning activities. Creative task performance data collection is obtained through observation with four skill parameters in the creative process in class through group work on extracting information, formulating problems, conveying ideas, formulating solutions. Observation data are also carried out during class activities to find out the creative process that occurs in the classroom as a material to consider the learning process that runs in accordance with the learning implementation plan. The results of learning in the form of knowledge understand concepts and procedures are carried out through pre-tests and posttests to provide a clear picture of the implementation of strategies and relationships between research variables.

\section{Results}

Description of research data in the form of primary research data is the treatment of learning strategies that have been implemented, the social skills possessed by students and the results of data analysis of learning outcomes using the same test and observation instruments from the research variables used in the study. Solving creative problems in giving learning has other intervention variables or treatment given is a dominant factor in solving creative problems.

\subsection{Social skills}

The social skills questionnaire results obtained information as many as 20 students entered the low social skills category group, and 52 students entered the high social skills category group. Students in low categories mostly have social skills problems outside of learning activities. Their ability to self-regulate, such as the responsibility for doing chores at home, arranging study hours at home, as well as their ability to know how well they can study (Figure 2).

\section{Chart Title}

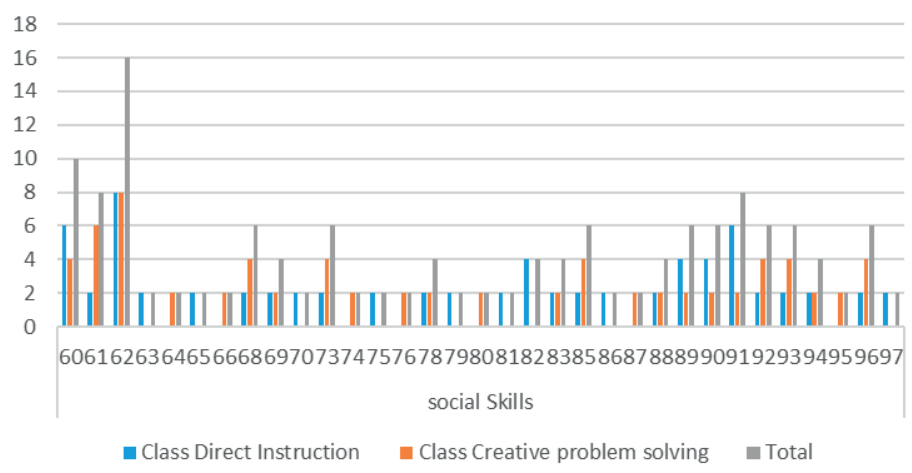

Figure 2. Statistics of social skills (source: created by authors) 


\subsection{The creative process and creative problem-solving}

The creative process is a series of interactive social activities in building shared concepts to solve problems provided through new ideas and ideas to solve the problems given. Giving an experience to students to solve the problems they face helps them to solve the problems they face at any time with creativity. The creative process is able to generate many ideas. However, not all good elections that are made will produce many benefits for groups and individuals (Figure 3).

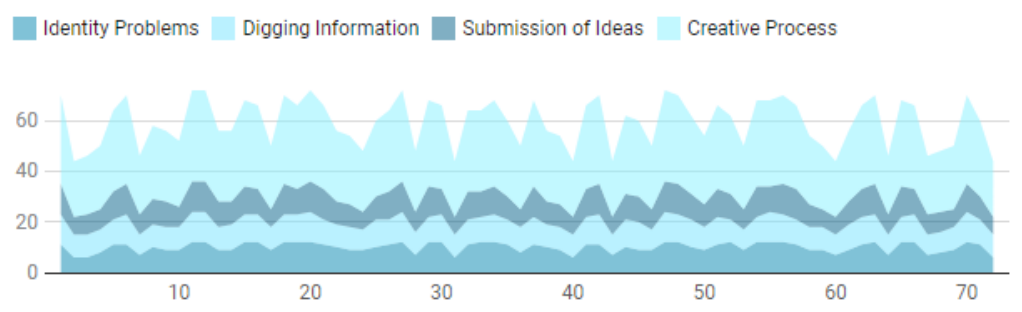

Figure 3. Statistics of creative process activities (source: created by authors)

The creative process is a structured discussion and has stages that must be completed as a procedure for doing something. The creative process starts with solving problems. The initial process of exploring a given problem, then gathering information about the problem found. This activity requires the participation of students actively involved to get good information about the interests they face. The objective background of individual characteristics has different reasons or learning objectives. The next creative process together provides ideas in the form of solutions to problems. The next creative process together provides ideas in the form of solutions to problems. The next stage discusses the ideas of each group member to choose creative problem-solving. The results of the creative process that occurs. The data obtained from the process of identifying problems, digging information, and submit ideas that have value. The data found that the creative process has a significant average value. After being done with the help found, some participants were unable to process properly.

\subsection{Social skills intervention}

Social skills are intervened by two factors which are sourced from internal and external psychological factors of students. Social skills can affect the process of interaction and can also affect social conditions in the classroom (Figure 4).

Research data, $52.7 \%$ of social skills are influenced by internal factors of students. This internal factor consists of the learning preparation process, the ability to work together, learning difficulties, self-regulation, and the ability to recognize yourself. The external social skill factor has an effect of $47.3 \%$. External factors are influenced by social conditions in the class, the selection of group members and the selection of learning strategies. The amount of internal factors students develops in the social skills they need must get serious attention. Students 


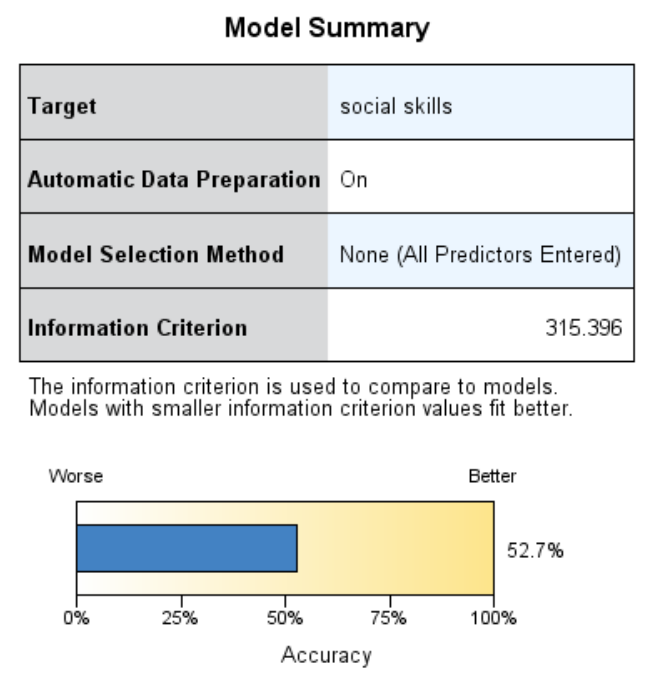

Figure 4. Social skills performance (source: created by authors)

who are only oriented toward mastery goals do not always have good adaptive results. For example, a student who is oriented towards high-level mastery goals understands the process of participation, and their activities are very low over time.

\subsection{Understand concepts and procedures with interventions}

The process of interaction of creative problem solving with social skills interventions obtained social skills data affect the creative process. This process has an influence on creative problem-solving. Social interaction in the classroom, the activeness of students participating in solving creative problems intended for the main problem given can solve the given problem and provide ideas for appropriate solutions to achieve the desired goals. Student intervention in understanding concepts and procedures is dominated by social skills possessed by students. The strategies provided through creative problem-solving strategies and direct learning have an effect if followed by class preparation, group member selection and motivation to interact and be active in discussions. Including learning about one's learning abilities and memories, knowing what learning strategies are useful, and planning and monitoring the learning process. More research on the application of creative problem-solving strategies to complete concepts and procedures needs to be done to solve the effect (Figure 5).

The results of the analysis of social skills, research data have a significant influence on the interaction process. Social skills are internal factors of students, which is the readiness of students to follow the learning process. Class becomes another factor that influences the interaction process. Class factors consist of problem-solving strategy assistance and directed learning strategies. Objective orientation is an important characteristic of students. The existence of these two solutions needs to be done, which factor analysis is better to discuss the interaction between the two intervention factors. 


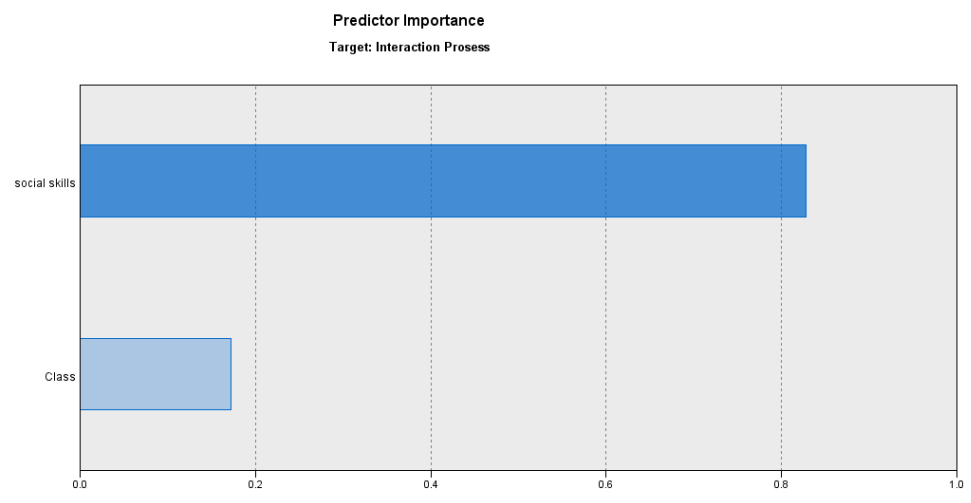

Figure 5. Interaction process (source: created by authors)

The level of understanding of concepts and procedures is influenced by the background of students' abilities which are sourced from social skills and the provision of creative problemsolving strategies and contribute the most to the creative process. Output data, interacting on the Wilks' lambda distribution (WLD) and Hotelling's trace is less than $0.05 \%$. This data provides the fact that social skill factors and problem-solving strategies have a significant effect. The next finding of social skills obtained by WLD and Hotelling's trace is the significant value of 0.00 , so that this social skill is a factor that has a very large influence. Class is the second factor that has a slight difference in the concepts and procedures of learners with a lambda value and a Hotelling's trace of significance 0.03 (Table 1).

The results of learning interactions discuss concepts and procedures approved by social skills data. Figure 6 estimates positive interactions by social skills. The application of creative problem-solving strategies has an effect of $0.171 \%$. Despite its smaller value, this strategy still has a creative process in learning. Creative problem solving that occurs is influenced

Table 1. The interaction of creative problem solving, creative processes and social skills (source: created by authors)

\begin{tabular}{|l|l|c|c|c|c|c|}
\hline \multicolumn{9}{|c|}{ Multivariate tests } \\
\hline \multirow{2}{*}{ Effect } & Value & $\mathrm{F}$ & Hypothesis df & Error df & Sig. \\
\hline \multirow{2}{*}{ Intercept } & Hotelling's trace & 280.446 & $9394.927 \mathrm{~b}$ & 2.000 & 67.000 & .000 \\
\cline { 2 - 7 } & Roy's largest root & 280.446 & $9394.927 \mathrm{~b}$ & 2.000 & 67.000 & .000 \\
\hline \multirow{2}{*}{ Class } & Hotelling's trace & .195 & $6.524 \mathrm{~b}$ & 2.000 & 67.000 & .003 \\
\cline { 2 - 7 } & Roy's largest root & .195 & $6.524 \mathrm{~b}$ & 2.000 & 67.000 & .003 \\
\hline \multirow{3}{*}{ Social skills } & Hotelling's trace & 1.469 & $49.206 \mathrm{~b}$ & 2.000 & 67.000 & .000 \\
\cline { 2 - 7 } & Roy's largest root & 1.469 & $49.206 \mathrm{~b}$ & 2.000 & 67.000 & .000 \\
\hline
\end{tabular}




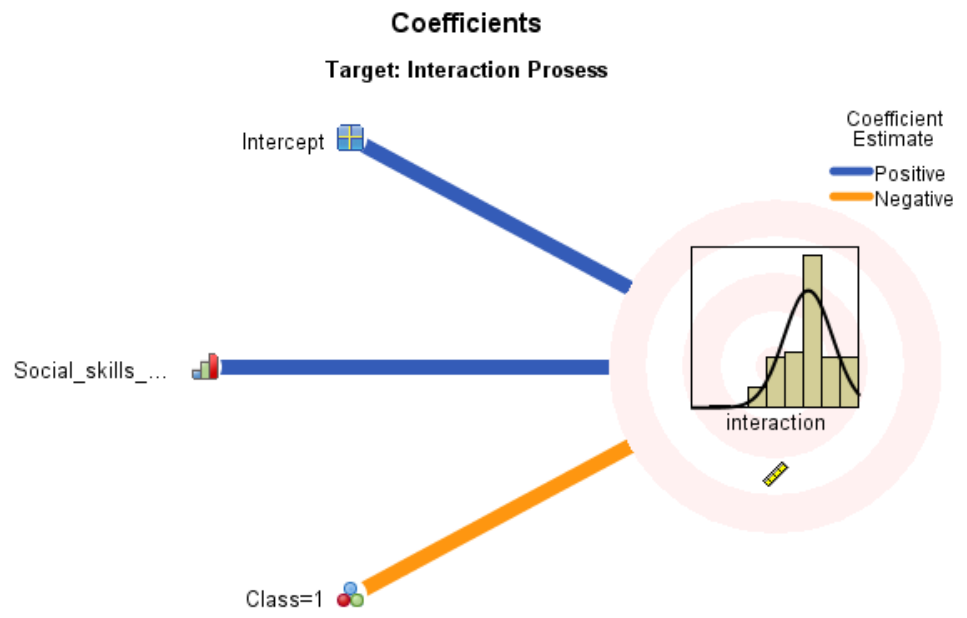

Figure 6. The estimated coefficient of the interaction process (source: created by authors)

by internal and external factors of students. Internal factors are very convincing in creating creative processes to solve creative problems that students solve.

\section{Discussion}

The background of students' skills is a major factor in how students respond to the stimuli that come. How students respond to the social environment they face, the ability to interact and solve the problems they face are intervened by many social skills they have. Creative process activities that occur in the classroom require the active role of students to be able to identify problems, explore information and convey ideas. The creative process that occurs in the classroom is dominated by social skills, how they are able to manage their learning time, understand their own learning style, understand their learning needs and take responsibility for the tasks given. Creative process skills are needed on information stored long-term memory, how to change the abilities needed to process further information in working memory, reflecting the transformational thinking of knowledge from education as individuals and society (Paas \& van Merriënboer, 1994; Paas et al., 2005; Sweller et al., 2019). The data obtained on average the creative process gets a perfect score but some students who have low skills have problems about the psychological background.

This fact shows that students who have low social skills, background have low self-regulation, especially in terms of self-aware ability outside of learning activities. Low self-control also has the impact of a lack of preparation and responsibility for the tasks given, thus impacting them when attending classroom learning. Social skills support the creative process carried out during learning activities so that the performance of creative tasks in finding creative problem solutions is also better. Social skills, which are internal factors such as self-regulation and self-efficacy, make them able to adjust learning activities and interact between 
students and students and teachers. The influence of social skills needs serious attention as initial information about the characteristics of learners, which are internal factors in students and affect their behaviour. These internal factors are their abilities in the learning process, their learning style abilities, learning abilities, self-regulating abilities, and self-understanding abilities. External factors have less influence in solving problems creatively. Students who are good at getting along with fellow group members mostly have good social skills so that they have a relationship between social skills in forming external factors. External factors create social processes, strategies to create creative processes and social environments in the classroom. Educators must be able to create successful external factors in creating creative processes that students can collaboratively and interact with. From an efficiency perspective, students' behaviour in the classroom will be more efficient if they have a higher social background than expected process performance goals based on continuous social skills training. If the experience of understanding yourself about social skills is inferior, then creative problem-solving performance does not fit the expected goals (Buisine et al., 2012; Estrada et al., 1994; Muis et al., 2018; Paas et al., 2005; Valqui Vidal, 2005).

The information obtained about how social skills interventions and the use of learning strategies in the classroom in students understand the concepts and procedures for assembling computers, the information obtained explains that interventions between high social skills and the use of learning strategies are related to the level of understanding of concepts and procedures. Social skills influence the implementation of learning strategies. Social skills also have a very strong influence in shaping creative processes in the classroom and in completing assignments creatively. According to the research data obtained, it is explained that the provision of creative problem-solving strategies and direct learning has little effect on students who have low social skills. Providing learning strategies require additional social environments in the classroom, group selection, class formation, and creating a good interactive environment. This means that learning can affect creativity, but the individual character is more dominant than the application of learning strategies. Social skills are characteristic of students as a diversity, so to improve high social skills requires repeated training. Creativity is the result of efforts made continuously and repeatedly so that it becomes a habit. Therefore, there needs to be a structured and planned effort to improve students' creativity into a life skill. Learning strategies with cognitive effects and social skills on learning by manipulating variability in learning tasks, social environment, group selection, student motivation can improve external social factor skills to build cognitive schemes and transfer knowledge and creative process skills that can be applied to problems new problem (Foster \& Yaoyuneyong, 2016; Huang, 2019; Paas et al., 2003, 2005; Schmitt et al., 2012; Wang et al., 2008).

\section{Conclusions}

Creative problem solving is mostly intervened by social skills in understanding concepts and procedures, and these social skills are related to internal student factors: readiness to learn, the ability to understand one's own needs, the ability to understand one's own learning style. Increasing social skills needs to be done as a form of their expertise in soft skills, which is very much needed. External factors are influenced by the class social environment, group 
formation, and class management. This factor can also affect the performance of creative tasks, especially students who have low social skills. Learning strategies have an influence on the creative process in the classroom but need to be done with strict guidance and good procedures. The importance of social participation in the creative process in the classroom needs to get more attention from the selection of inappropriate strategies.

\section{References}

Abdulla, A. M., \& Cramond, B. (2018). The creative problem finding hierarchy: A suggested model for understanding problem finding. Creativity: Theories - Research - Applications, 5(2), 197-229. https://doi.org/10.1515/ctra-2018-0019

Ames, C., \& Archer, J. (1988). Achievement goals in the classroom: students' learning strategies and motivation processes. Journal of Educational Psychology, 80(3), 260-267. https://doi.org/10.1037/0022-0663.80.3.260

An, Ch. (2019). The content and role of intrinsic motivation in creative work: the importance of seeking “Enjoyment”. Creativity Studies, 12(2), 280-290. https://doi.org/10.3846/cs.2019.6451

Azevedo, R., Cromley, J. G., \& Seibert, D. (2004). Does adaptive scaffolding facilitate students' ability to regulate their learning with hypermedia? Contemporary Educational Psychology, 29(3), 344-370. https://doi.org/10.1016/j.cedpsych.2003.09.002

Basadur, M., Gelade, G., \& Basadur, T. (2014). Creative problem-solving process styles, cognitive work demands, and organizational adaptability. The Journal of Applied Behavioral Science, 50(1), 80-115. https://doi.org/10.1177/0021886313508433

Buisine, S., Besacier, G., Aoussat, A., \& Vernier, F. (2012). How do interactive tabletop systems influence collaboration? Computers in Human Behavior, 28(1), 49-59.

https://doi.org/10.1016/j.chb.2011.08.010

Carver, Ch. S., \& Scheier, M. F. (2005). On the structure of behavioral self-regulation. In M. Boekaerts, P. R. Pintrich, \& M. Zeidner (Eds.), Handbook of self-regulation (pp. 41-84). Academic Press.

Chowdhry, S. (2016). Student's perception of effectiveness of a technology enhanced problem based learning environment in a mechanical engineering module. Journal of Today's Ideas - Tomorrow's Technologies, 4(1), 15-32. https://doi.org/10.15415/jotitt.2016.41002

Estrada, C. A., Isen, A. M., \& Young, M. J. (1994). Positive affect improves creative problem solving and influences reported source of practice satisfaction in physicians. Motivation and Emotion, 18(4), 285-299. https://doi.org/10.1007/BF02856470

Flavell, J. H. (1979). Metacognition and cognitive monitoring: a new area of cognitive-developmental inquiry. American Psychologist, 34(10), 906-911. https://doi.org/10.1037/0003-066X.34.10.906

Florida, R., Mellander, Ch., Stolarick, K., Silk, K., Matheson, Z., \& Hopgood, M. (2011). Creativity and prosperity: The Global Creativity Index. Martin Prosperity Institute.

Foster, J., \& Yaoyuneyong, G. (2016). Teaching innovation: equipping students to overcome real-world challenges. Higher Education Pedagogies, 1(1), 42-56. https://doi.org/10.1080/23752696.2015.1134195

Gillies, R. M. (2019). Promoting academically productive student dialogue during collaborative learning. International Journal of Educational Research, 97, 200-209. https://doi.org/10.1016/j.ijer.2017.07.014

Huang, T.-Ch. (2019). Do different learning styles make a difference when it comes to creativity? An Empirical Study, Computers in Human Behavior, 100, 252-257. https://doi.org/10.1016/j.chb.2018.10.003

Isari, D., Pontiggia, A., \& Virili, F. (2016). Working with tweets vs. working with chats: an experiment on collaborative problem solving. Computers in Human Behavior, 58, 130-140.

https://doi.org/10.1016/j.chb.2015.12.052 
Khuziakhmetov, A. N., \& Gorev, P. M. (2017). Introducing learning creative mathematical activity for students in extra mathematics teaching. Bolema: Boletim de Educação Matemática, 31(58), 642-658. https://doi.org/10.1590/1980-4415v31n58a06

Lin, Sz.-Y., \& Chang, H.-I. (2020). Does open-plan office environment support creativity? The mediating role of activated positive mood. Creativity Studies, 13(1), 1-20. https://doi.org/10.3846/cs.2020.10332

Merrell, K. W. (2001). Assessment of children's social skills: recent developments, best practices, and new directions. Exceptionality: A Special Education Journal, 9(1-2), 3-18. https://doi.org/10.1207/S15327035EX091\&2_2

Muis, K. R., Chevrier, M., \& Singh, C. A. (2018). The role of epistemic emotions in personal epistemology and self-regulated learning. Educational Psychologist, 53(3), 165-184. https://doi.org/10.1080/00461520.2017.1421465

Navickienè, V., Sederevičiūtè-Pačiauskienė, Ž., Valantinaite, I., \& Žilinskaitè-Vytienè, V. (2019). The relationship between communication and education through the creative personality of the teacher. Creativity Studies, 12(1), 49-60. https://doi.org/10.3846/cs.2019.6472

Paas, F., Camp, G., \& Rikers, R. (2001). Instructional compensation for age-related cognitive declines: effects of goal specificity in maze learning. Journal of Educational Psychology, 93(1), 181-186. https://doi.org/10.1037/0022-0663.93.1.181

Paas, F. G. W. C., \& Merriënboer, van J. G. (1994). Variability of worked examples and transfer of geometrical problem-solving skills: a cognitive-load approach. Journal of Educational Psychology, 86(1), 122-133. https://doi.org/10.1037/0022-0663.86.1.122

Paas, F., Tuovinen, J. E., Merriënboer, van J. J. G., \& Darabi, A. A. (2005). A motivational perspective on the relation between mental effort and performance: optimizing learner involvement in instruction. Educational Technology Research and Development, 53(3), 25-34. https://doi.org/10.1007/BF02504795

Paas, F., Tuovinen, J. E., Tabbers, H., \& Gerven, van P. W. M. (2003). Cognitive load measurement as a means to advance cognitive load theory. Educational Psychologist, 38(1), 63-71. https://doi.org/10.1207/S15326985EP3801_8

Schmidt, H. G., Loyens, S. M. M., Gog, van T., \& Paas, F. (2007). Problem-based learning is compatible with human cognitive architecture: commentary on Kirschner, Sweller, and Clark (2006). Educational Psychologist, 42(2), 91-97. https://doi.org/10.1080/00461520701263350

Schmitt, L., Buisine, S., Chaboissier, J., Aoussat, A., \& Vernier, F. (2012). Dynamic tabletop interfaces for increasing creativity. Computers in Human Behavior, 28(5), 1892-1901. https://doi.org/10.1016/j.chb.2012.05.007

Schult, J., Stadler, M., Becker, N., Greiff, S., \& Sparfeldt, J. R. (2017). Home alone: complex problem solving performance benefits from individual online assessment. Computers in Human Behavior, 68, 513-519. https://doi.org/10.1016/j.chb.2016.11.054

Sternberg, R. J. (1985). Implicit theories of intelligence, creativity, and wisdom. Journal of Personality and Social Psychology, 49(3), 607-627. https://doi.org/10.1037/0022-3514.49.3.607

Sweller, J., Merriënboer, van J. J. G., \& Paas, F. (2019). Cognitive architecture and instructional design: 20 years later. Educational Psychology Review, 31, 261-292. https://doi.org/10.1007/s10648-019-09465-5

Valqui Vidal, R. V. (2005). Creativity for operational researchers. Investigação Operacional, 25, 1-24.

Wang, H.-Ch., Chang, Ch.-Y., \& Li, T.-Y. (2008). Assessing creative problem-solving with automated text grading. Computers and Education, 51(4), 1450-1466.

https://doi.org/10.1016/j.compedu.2008.01.006 